\title{
ANALISIS KESESUAIAN WISATA DI PANTAI NYALO [KAWASAN MANDEH] KABUPATEN PESISIR SELATAN, SUMATERA BARAT
}

\author{
Suitability Analysis of Tourism in the Nyalo Beach [Mandeh Region] \\ Pesisir Selatan Regency of West Sumatra
}

\section{Putri Dellia Mukhtar, Siti Rudiyanti*), Frida Purwanti}

Program Studi Manajemen Sumberdaya Perairan, Jurusan Perikanan

Fakultas Perikanan dan Ilmu Kelautan, Universitas Diponegoro

Jl. Prof. Sudato, SH, Tembalang, Semarang, Jawa Tengah - 50275, Telp/Fax. +6224 7474698

Email: putridellia94@yahoo.com

\begin{abstract}
ABSTRAK
Kawasan Mandeh merupakan kawasan yang terletak di Kecamatan Koto IX Tarusan Kabupaten Pesisir Selatan, kawasan ini telah dijadikan destinasi utama sektor pariwisata bahari Provinsi Sumatera Barat. Salah satu pantai di kawasan tersebut yang akan dikembangkan menjadi daerah tujuan wisata adalah Pantai Nyalo. Tujuan penelitian ini untuk mengetahui potensi wisata yang dapat dikembangkan di Pantai Nyalo, persepsi responden terhadap daya tarik wisata di Pantai Nyalo dan nilai Indeks Kesesuaian Wisata (IKW) Pantai Nyalo.Penelitian dilakukan pada bulan Mei-Juni 2016. Metode yang digunakan pada penelitian ini adalah metode penelitian kuantitatif menggunakan Indeks Kesesuaian Wisata (IKW) dan metode deskriptif dengan menyebar kuisioner kepada 30 responden masyarakat menggunakan teknik sampling purposive sampling dan 30 responden wisatawan menggunakan accidental sampling. Potensi wisata Pantai Nyalo terdapat pada kondisi fisik pantai yang indah, serta jenis kegiatan atau daya tarik wisatanya yaitu berenang, olahraga pantai, dan panorama Puncak Paku.Secara umum daya tarik wisata di Pantai Nyalo dipersepsikan positif oleh responden.IKW Pantai Nyalo di stasiun I adalah 96\%, sedangkan stasiun II dan III adalah 92\%.Hal ini menunjukkan bahwa kawasan Pantai Nyalo tergolong dalam kategori S1 atau sangat sesuai untuk kegiatan wisata pantai.
\end{abstract}

Kata Kunci: Kesesuaian Wisata; Pantai Nyalo; Kabupaten Pesisir Selatan

\begin{abstract}
Mandeh Region is an area located in the Koto IX Tarusan of Pesisir Selatan Regency, this area has been used as the main marine tourism destinations in the province of West Sumatra. One of beach in the area that will be developed into a tourist destination is the Nyalo Beach. The purpose of this study are to know tourism potential that can be developed in the Nyalo Beach, perception of respondents to tourism attractions in the Nyalo Beach and to determine Tourism Suitability Index $(I K W)$ in Nyalo Beach. The study was conducted from May to June 2016. The methods used in this research are quantitative research method using Tourism Suitability Index (IKW) and descriptive method by spreading questionnaire to 30 local communities respondents using purposive sampling and 30 visitors respondents using accidental sampling. The Nyalo Beach tourism potential is in the physical condition of beautiful beaches as well as the type of tourism activities or attractions, i.e swimming, beach sports, and panoramic from the Puncak Paku. In general, the perception of tourism attractions in the Nyalo Beach is positively perceived by respondents. IKW of the Nyalo Beach in station I is $96 \%$ while station II and III are 92\%. This shows that the Nyalo Beach areas belongs to category S1 or very suitable for beach tourism activities.
\end{abstract}

Keywords: Tourism Suitability; Nyalo Beach; Pesisir Selatan Regency

*) Penulis penanggungjawab

\section{PENDAHULUAN}

Wisata minat khusus adalah suatu bentuk perjalanan wisata, dimana wisatawan melakukan perjalanan atau mengunjungi suatu tempat karena memiliki sesuatu minta atau motivasi khusus mengenai suatu jenis objek atau kegiatan yang dapat di temui atau dilakukan di sebuah lokasi wisata (Hartono, 2015). Salah satu tujuan wisata minat khusus di Sumatera Barat adalah Kawasan Mandeh yang berada di Kabupaten Pesisir Selatan, walaupun memiliki jarak yang cukup jauh dari Kota Padang, tetapi kawasan ini memiliki keindahan alam yang sangat menawan, sehingga keindahan ini dimanfaatkan oleh pemerintah kabupaten untuk dikembangkan menjadi

\footnotetext{
${ }^{\circ}$ Copyright by Management of Aquatic Resources (MAQUARES)
} 
daerah wisata. Kawasan ini terletak di Kecamatan Koto XI, yang telah dijadikan destinasi utama sektor pariwisata bahari dan dimasukkan ke dalam Rencana Induk Pengembangan Pariwisata Nasional (RIPPNAS) bersama Kawasan Biak dan Bunaken. Kawasan Mandeh yang dijuluki sebagai The Paradise in The South, memiliki luas \pm 18.000 Ha yang terdiri dari pulau-pulau kecil, yaitu Pulau Cubadak, Pulau Pagang, Pulau Sirojong, Pulau Setan, Pulau Marak, Pulau Pasumpahan, Pulau Pamutusan, Suwarnadwipa, Teluk Sikulo dan lain sebagainya (Ridwan, 2013).

Beberapa parameter ekologi yang digunakan untuk melihat potensi kawasan antara lain; kedalaman perairan, tipe pantai, lebar pantai, material dasar perairan, kecepatan arus, kemiringan pantai kecerahan perairan, penutupan lahan, biota berbahaya, ketersediaan air tawar sebagai acuan dalam mendapatkan nilai Indeks Kesesuaian Wisata. Parameter lain yaitu, kondisi sosial dan ekonomi masyarakat setempat serta pengunjung digunakan sebagai data pendukung untuk menilai persepsi responden terhadap daya tarik wisata di Pantai Nyalo.Analisis kesesuaian wisata akan memberikan gambaran apakah objek wisata tersebut dapat dikatakan sesuai atau tidak sebagai objek wisata pantai, sehingga tujuan dari penelitian ini adalah mengetahui potensi wisata yang dapat dikembangkan, persepsi respondenterhadap daya tarik wisata dan nilai Indeks Kesesuaian Wisata (IKW) di Pantai Nyalo.

\section{MATERI DAN METODE PENELITIAN}

Penelitian dilaksanakan pada bulan Mei sampai bulan Juni 2016 di Pantai Nyalo, Nagari/Kampung Nyalo Mudiak Air di Kecamatan Koto XI Tarusan Kabupaten Pesisir Selatanyang berjarak 56 Km dari Kota Padang, Sumatera Barat.

\section{Alat dan Bahan}

Alat yang digunakan adalah GPS (Global Positioning System), Rollmeter, Secchi disc, tongkat berkala, tongkat berukuran $100 \mathrm{~cm}$, waterpass, bola arus, stopwatch, kamera, dan alat tulis. Bahan yang digunakan meliputi data kuisioner data sekunder yang didapatkan dari instansi terkait, buku dan jurnal.

\section{Metode}

Penelitian menggunakan metode kuantitatif untuk menghitung Indeks Kesesuaian Wisata sesuai Yulianda (2007) dan metode deskriptif untuk menganalisa kuisioner, dengan teknik pusposive sampling untuk memilih responden masyarakat dan accidental sampling untuk wisatawan. Penentuan titik pengambilan sampel dilakukan di tiga stasiun di sepanjang pantai.Hal ini didasarkan pertimbangan bahwa aktivitas pengunjung dilakukan di stasiun tersebut.Koordinat stasiun penelitian disajikan pada Tabel 1.

Tabel 1. Koordinat Stasiun Penelitian

\begin{tabular}{|c|c|c|c|}
\hline \multirow{2}{*}{ No. } & \multirow{2}{*}{ Stasiun } & \multicolumn{2}{|c|}{ Koordinat } \\
\hline & & Latitude & Longitude \\
\hline 1 & Stasiun 1 & $1^{\circ} 10^{\prime} 53,24^{\prime \prime} \mathrm{S}$ & $100^{\circ} 24^{\prime} 00,49^{\prime \prime} \mathrm{E}$ \\
\hline 2 & Stasiun 2 & $1^{\circ} 10^{\prime} 54,43$ " S & $100^{\circ} 24^{\prime} 03,32^{\prime \prime} \mathrm{E}$ \\
\hline 3 & Stasiun 3 & $1^{\circ} 10^{\prime} 55,75^{\prime \prime} \mathrm{S}$ & $100^{\circ} 24^{\prime} 04,63$ " E \\
\hline
\end{tabular}

Cara pengukuran sampel dilakukan dengan cara pengambilan parameter biofisikuntuk menilai Indeks Kesesuaian Wisata (IKW) pantai yaitu: kedalaman perairan dengan pengukuran15 meter ke arah laut dari garis pantai pantai; tipe pantai dari pengamatan visual dengan mengamati jenis dan warna pasirnya; lebar pantai dengan rollmeter, jarak antara vegetasi terakhir yang ada di pantai dengan batas pasang tertinggi; material dasar perairan dengan mengamati bentuk substrat; kecepatan arus dengan pengukuran 15 meter ke arah laut dari garis pantai menggunakan bola arus; kemiringan pantai dengan menggunakan tongkat berukuran $100 \mathrm{~cm}$ diletakkan secara horizontal di atas pasir dan di atas kayu diletakkan waterpass, ketinggian dihitung dengan rollmeter kemudian sudut kemiringan $(\alpha)$ didapatkan dari rumus : $\alpha=\operatorname{arc} \tan \frac{\mathrm{Y}}{\mathrm{X}}$, Y (jarak antara garis tegak lurus yang dibentuk) dan $\mathrm{X}$ (panjang kayu, 100cm); kecerahan perairan dengan pengukuran 15 meter ke arah laut dari garis pantai menggunakan Secchi disk; penutupan lahan dari pengamatan daerah di sekitar pantai; penentuan biota berbahaya dengan mengamati biota yang ada di Pantai Nyalo yang tergolong berbahaya, dan ketersediaan air tawar dengan mengamati jarak sumber air bersih terdekat dari pantai.

Analisis kesesuaian wisata menggunakan matriks kesesuaian yang telah diberi penilaian terhadap bobot dan skor dari semua parameter dengan menggunakan rumus:

$$
\mathrm{IKW}=\sum\left\lfloor\frac{N i}{N_{m a k s}}\right\rfloor \times 100 \%
$$


Keterangan:

IKW $=$ Indeks Kesesuaian Wisata $(\%)$

$N i=$ Nilai parameter ke-i (bobot $\mathrm{x}$ skor)

$N$ maks $=$ Nilai maksimum dari suatu kategori wisata

\section{HASIL DAN PEMBAHASAN}

\section{HASIL}

\section{Deskripsi Umum Daerah Penelitian}

Pantai Nyalo merupakan salah satu pantai yang berada di Kawasan Mandeh Kabupaten Pesisir Selatan. Secara geografis Pantai ini terletak pada posisi $1^{\circ} 10^{\prime}-1^{\circ} 18^{\prime}$ LS dan 100 $21^{\prime}$ - $100^{\circ} 40^{\prime}$ BT. Pantai ini berada di Nagari/ Kampung Nyalo Mudiak Air dengan luas Nagari sebesar 21,34 km².Peta lokasi penelitian disajikan pada Gambar 1 .

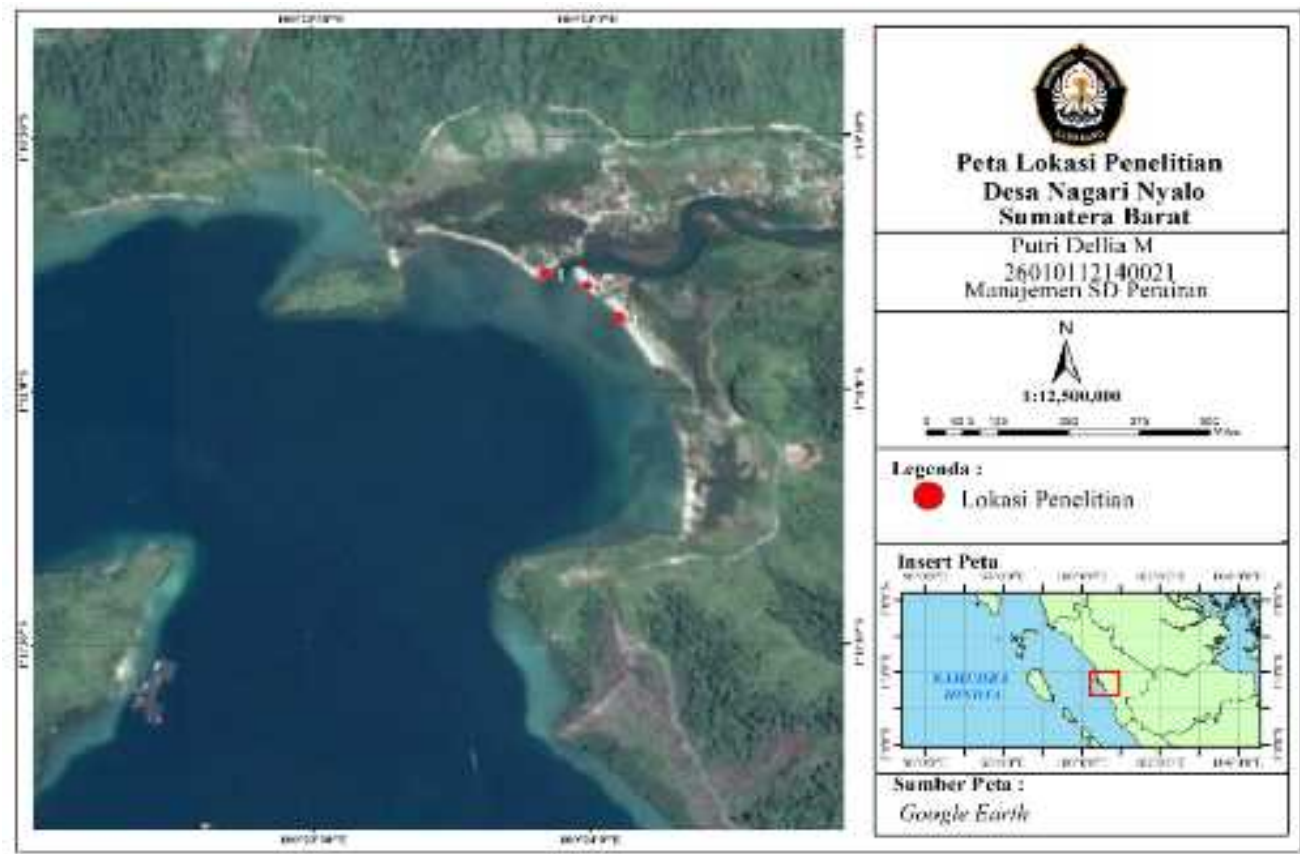

Gambar 1. Peta lokasi penelitian

Pantai Nyalo secara umum dikelilingi gunung dan bukit-bukit, yang merupakan perpanjangan dari Bukit Barisan, dengan tinggi dari permukaan laut berkisar 2-25 meter.Pantai ini beriklim tropis, dengan temperatur $23^{\circ} \mathrm{C}-32^{\circ} \mathrm{C}$ di siang hari dan $20^{\circ} \mathrm{C}-28^{\circ} \mathrm{C}$ di malam hari. Curah hujan di daerah ini 224,63 Mm/bulan (Meteorologi IV Maritim Teluk Bayur, 2016). Bentuk dari morfologi Pantai Nyalo yang berhadapan dengan Kabupaten Kepulauan Mentawai dan Samudra Hindia, dapat menimbulkan aktivasi gelombang dan akan mempengaruhi pasang surut. Gelombang yang terjadi sangat dipengaruhi oleh angin yang bertiup dari Samudera Hindia (DKP, 2015).Pola pasang surut yang terjadi adalah tipe diurnal. Fluktuasi pasang di daerah penelitian berkisar 0,5-1,5 meter. Sekitar bulan Mei 2016 arus dominan mengalir ke arah tenggara sampai timur laut.Secara umum pola sirkulasi air di perairan daerah penelitian bergerak dari utara dan barat laut ke arah tenggara.Pola tersebut dikatakan tetap sepanjang tahun.Namun, karena posisi Pantai Nyalo relatif terlindung karena keberadaan pulau-pulau kecil di sekitarnya serta geomorfologi pantainya, sehingga pengaruh angin menimbulkan gelombang menjadi tereduksi dan menjadikan perairan di Pantai Nyalo tergolong perairan yang tenang (Wali Nagari Nyalo, 2016).

Pantai Nyalo terletak cukup jauh dari Kota Padang, terdapat dua alternatif untuk dapat menuju pantai ini yaitu melalu jalur darat dan jalur laut. Jalur darat dapat ditempuh dengan waktu $\pm 2,5$ jam dengan melewati Pasar Tarusan melalui Simpang Carocok atau melalui Bungus menuju ke Arah Sungai Pisang dan langsung menuju ke Kampung Nyalo. Kondisi jalan menuju ke Pantai Nyalo tergolong jalan yang kecil. Jalur laut dapat ditempuh dengan Kapal Motor cepat (KM) Bintang Mandeh yang berkapasitas 50 orang dengan tarif Rp. 300.000,-per orang dengan rute Muaro Padang langsung ke Dermaga Tarusan (Kawasan Mandeh) dengan waktu tempuh \pm 1 jam. Allternatif lain bisa di tempuh dengan naik kapal dari Pelabuhan Bungus, Gaum, Teluk Baru dengan tarif $\operatorname{Rp} 50.000$,- per orang dengan waktu tempuh \pm 1,5 jam menuju ke Dermaga Tarusan. 


\section{Potensi Wisata Pantai Nyalo}

Berdasarkan kondisi ekologis, Pantai Nyalo terdapat beberapa potensi yang dapat dikembangkan menjadi objek wisata adalah sebagai berikut:

a. Panorama keindahan sekitar pantai, dapat terlihat lautan yang berwarna biru, hamparan pasir putih disepanjang pantai yang ditumbuhi dengan pohon kelapa dan jajaran bukit-bukit hijau yang menawan.

b. Aktivitas berenang di pantai, karena kedalaman pantai yang tidak terlalu dalam dan tergolong pantai dengan ombak yang kecil.

c. Bagian Utara terdapat lahan terbuka dengan pasir putih yang dapat digunakan untuk olahraga pantai seperti Voli Pantai dan Sepakbola.

d. Terdapat Puncak Paku yang dapat dijadikan objek panorama yang berjarak $\pm 4 \mathrm{~km}$ untuk melihat keindahan laut.

Keempat potensi wisata yang dapat dikembangkan di Pantai Nyalo tersaji pada Gambar 2.

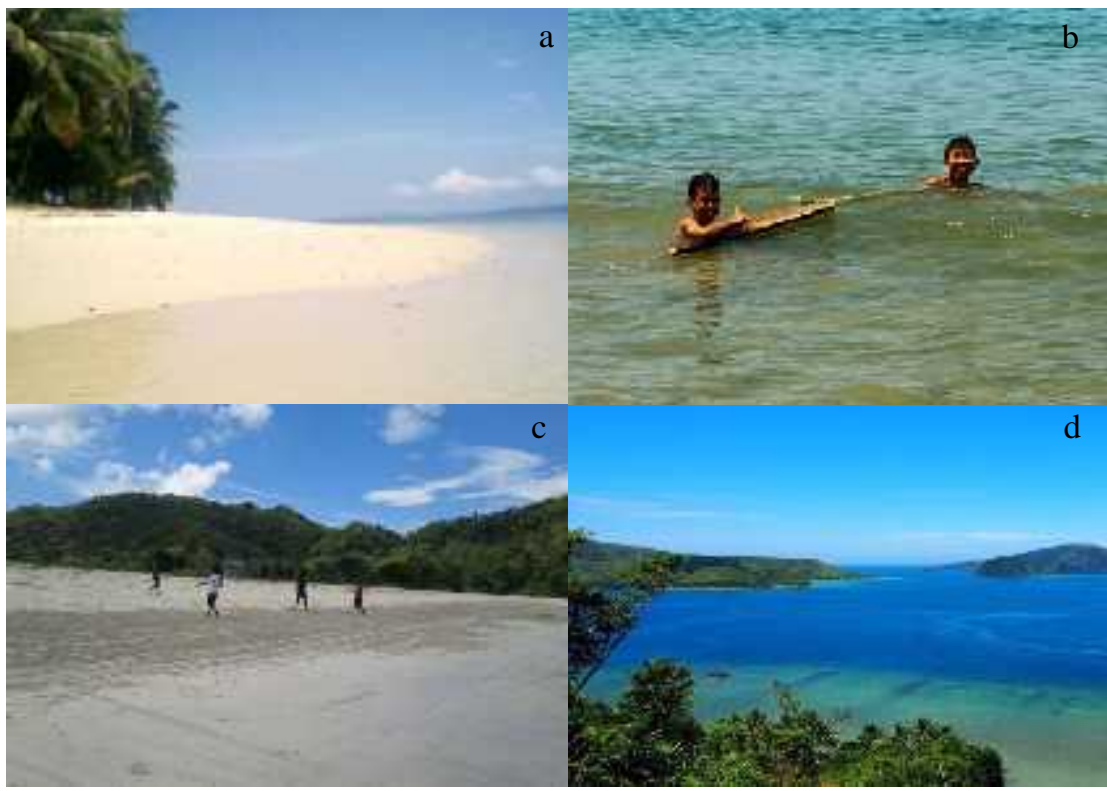

Gambar 2. Potensi wisata di Pantai Nyalo

\section{Persepsi Responden terhadap Daya Tarik Wisata dan Sarana Prasarana}

Hasil wawancara terhadap 30 responden masyarakat dan 30 wisatawan Pantai Nyalo mengenai penilaian terhadap daya tarik wisata dan sarana prasarana yang ada di Pantai Nyalo dapat dilihat pada Tabel 2.

Tabel 2. Persepsi Responden terhadap Daya Tarik Wisata dan Sarana Prasarana

\begin{tabular}{|c|c|c|c|c|c|c|c|c|c|c|}
\hline Kategori & \multicolumn{5}{|c|}{ Masyarakat (\%) } & \multicolumn{5}{|c|}{ Wisatawan (\%) } \\
\hline Daya tarik wisata & 5 & 4 & 3 & 2 & 1 & 5 & 4 & 3 & 2 & 1 \\
\hline Pemandangan alam & 17 & 83 & - & - & - & 40 & 60 & - & - & - \\
\hline Pasir pantai & 23 & 77 & - & - & - & 33 & 67 & - & - & - \\
\hline Rekreasi berenang & 10 & 90 & - & - & - & 23 & 77 & - & - & - \\
\hline Kuliner & - & - & - & 77 & 23 & - & - & - & 40 & 60 \\
\hline Olahraga Pantai & 20 & 23 & 57 & - & - & 10 & 47 & 43 & - & - \\
\hline \multicolumn{11}{|l|}{ Sarana prasarana } \\
\hline Areal parkir & - & - & 67 & 33 & - & - & - & 77 & 23 & - \\
\hline $\mathrm{WC}$ & - & 33 & 33 & 33 & - & - & 40 & 40 & 20 & - \\
\hline Mushola & - & 83 & 17 & - & - & - & 100 & - & - & - \\
\hline Penginapan & - & - & - & 30 & - & - & - & - & 30 & - \\
\hline Tempat sampah & - & 53 & 47 & - & - & - & 50 & 50 & - & - \\
\hline $\begin{array}{l}\text { Kios/ warung } \\
\text { makan }\end{array}$ & - & 17 & 50 & 33 & - & - & 20 & 33 & 47 & - \\
\hline Pos informasi & - & - & - & 100 & - & - & - & - & 100 & - \\
\hline
\end{tabular}

\section{Keterangan:}

$5=$ Sangat menarik/ Sangat baik

$4=$ Menarik/ Baik
3 = Cukup menarik / Cukup baik

$2=$ Kurang menarik/ Kurang baik
1 = Tidak menarik/

Tidak baik

Indeks Kesesuaian Wisata di Pantai Nyalo 
Kesesuaian wilayah untuk wisata pantai ditentukan dengan menggunakan Indeks Kesesuaian Wisata (IKW).Hasil perhitungan indeks kesesuaian wisata pantai di kawasan Pantai Nyalo disajikan pada Tabel 3.

Tabel 3. Indeks Kesesuaian Wisata di Pantai Nyalo

\begin{tabular}{|c|c|c|c|c|c|c|c|}
\hline \multirow{2}{*}{ No } & \multirow{2}{*}{ Parameter } & \multicolumn{6}{|c|}{ Stasiun } \\
\hline & & I & Ni (bxs) & II & Ni (bxs) & III & Ni (bxs) \\
\hline 1. & $\begin{array}{l}\text { Kedalaman } \\
\text { perairan }(\mathrm{m})\end{array}$ & 0,95 & 15 & 1,32 & 15 & 1,25 & 15 \\
\hline 2. & Tipe pantai & Pasir putih & 15 & Pasir putih & 15 & Pasir putih & 15 \\
\hline 3. & Lebar pantai $(\mathrm{m})$ & 17,5 & 15 & 20 & 15 & 20 & 15 \\
\hline 4. & $\begin{array}{l}\text { Material dasar } \\
\text { perairan }\end{array}$ & Pasir & 9 & Pasir & 9 & Pasir & 9 \\
\hline 5 & $\begin{array}{l}\text { Kecepatan rus } \\
(\mathrm{m} / \mathrm{s})\end{array}$ & 0,9 & 9 & 0,14 & 9 & 0,15 & 9 \\
\hline 6. & $\begin{array}{l}\text { Kemiringan } \\
\text { pantai }\left(^{\circ}\right)\end{array}$ & 4,8 & 9 & 5,4 & 9 & 5,5 & 9 \\
\hline 7 & $\begin{array}{l}\text { Kecerahan } \\
\text { perairan (m) }\end{array}$ & 0,6 & 0 & 1 & 0 & 0,91 & 0 \\
\hline 8 & $\begin{array}{l}\text { Penutupan lahan } \\
\text { pantai }\end{array}$ & $\begin{array}{c}\text { Lahan } \\
\text { terbuka, } \\
\text { pohon } \\
\text { kelapa }\end{array}$ & 3 & $\begin{array}{c}\text { Semak } \\
\text { belukar } \\
\text { rendah, } \\
\text { savana }\end{array}$ & 2 & $\begin{array}{l}\text { Semak } \\
\text { belukar } \\
\text { rendah, } \\
\text { savana }\end{array}$ & 2 \\
\hline 9 & Biota berbahaya & Tidak ada & 3 & Tidak ada & 3 & Tidak ada & 3 \\
\hline 10 & $\begin{array}{l}\text { Ketersediaan air } \\
\text { tawar }(\mathrm{km})\end{array}$ & 0,15 & 3 & 1,5 & 1 & 1,5 & 1 \\
\hline & Total $\sum(\mathrm{Ni})$ & & 81 & & 78 & & 78 \\
\hline & $\begin{array}{l}\text { Indeks Kesesuai } \\
\text { Wisata }(\%)\end{array}$ & & 96 & & 92 & & 92 \\
\hline & Kriteria & & S1 & & S1 & & S1 \\
\hline
\end{tabular}

\section{PEMBAHASAN}

\section{Potensi Wisata Pantai Nyalo}

Berdasarkan hasil pengamatan sumberdaya alam di Pantai Nyalo, pantai ini memiliki potensi wisata yang dapat dikembangkan untuk menarik wisatawan.Panorama bukit-bukit yang mengelilingi pantai, putihnya pasir di sepanjang pantai dan ditumbuhi pohon kelapa yang menjadikan pantai ini terlihat lebih indah dan sejuk serta birunya warna laut salah satu daya tarik dari pantai ini.Salah satu potensi yang dapat menjadi atraksi utawa wisata di Pantai Nyalo adalah aktivitas berenang.Hal ini karena kondisi perairan tergolong dengan ombak yang kecil dan kedalaman yang dangkal sehingga pengunjung anak-anak maupun orang dewasa dapat berenang dengan aman di pantai ini.

Bagian utara di Pantai Nyalo terdapat lahan pasir putih yang luas yang dapat dimanfaatkan sebagai lahan untuk berolahraga pantai seperti voli pantai dan sepakbola.Sekitar $\pm 4 \mathrm{~km}$ dari pantai ke bagian Selatan pantai terdapat bukit yang dinamakan Puncak Paku.Lokasi ini merupakan salah satu atraksi yang melengkapi kegiatan wisata di Pantai Nyalo.Hal ini karena dari bukit tersebut wisatawan dapat melihat keindahan laut dan pulau-pulau lain yang berada di sekitar Pantai Nyalo, ini dapat menjadi peluang untuk menarik wisatawan dengan tujuan utama untuk fotografi.

Melihat keindahan alam merupakan salah satu bentuk relaksasi yang didapatkan ketika melakukan kegiatan wisata.Potensi sumberdaya alam yang masih alami dan iklim tropis yang cocok untuk berwisata yang terdapat di Pantai Nyalo memberikan atraksi wisata dan menjadi faktor pendukung bagi pengembangan kawasan wisata di Pantai Nyalo ini. Menurut Kusumaningrum (2009), potensi dan jenis sumberdaya alam dapat menjadi daya tarik tersendiri bagi pengembangan suatu kawasan wisata pantai. Jika sumberdaya alam yang terdapat dalam kawasan kurang menarik dan kondisinya mulai mengalami kerusakan, hal ini akan mengakibatkan penurunan minat wisatawan atau bahkan hilangnya pesona wisata kawasan tersebut.

\section{Persepsi Responden terhadap Daya Tarik Wisata dan Sarana Prasarana}

Berdasarkan hasil wawancara dengan responden masyarakat lokal dan wisatawan Pantai Nyalo, keduanya memiliki persepsi yang positif terhadap daya tarik wisata pantai ini. Pada daya tarik wisata pemandangan alam, pasir pantai, rekreasi berenang dan olahraga pantai, keduanya memiliki persepsi yang samahanya berbeda pada jumlah persentasenya saja (Tabel 2). $83 \%$ masyarakat dan $60 \%$ wisatawan menyatakan bahwa Pantai Nyalo menarik dalam menawarkan pemandangan alam yang indah.77\% masyarakat dan $67 \%$ wisatawan menyatakan putihnya pasir pantai ini juga menarik.90\% masyarakat dan $77 \%$ wisatawan tertarik

\footnotetext{
${ }^{\complement}$ Copyright by Management of Aquatic Resources (MAQUARES)
} 
pada rekreasi berenang. $57 \%$ masyarakat dan $43 \%$ wisatawan menyatakan sedang atau cukup untuk lahan berolahraga pantai.

Perbedaan jumlah persentase ini dipengaruhi oleh karakteristik responden wisatawan yang lebih banyak pada usia muda dan berprofesi sebagai pelajar, berbeda dengan responden masyarakat yang lebih banyak pada usia dewasa dan berprofesi sebagai nelayan yang telah menekuni pekerjaan selama 5-10 tahun, sehingga sangat mengetahui indahnya pesona Pantai Nyalo. Apabila dilihat dari kuliner yang ada di pantai ini kedua responden memiliki persepsi yang negatif yaitu, 76\% masyarakat menyatakan kurang menarik apabila nantinya pantai akan banyak dikunjungi dan 60\% wisatawan menyatakan tidak menarik. Hal ini karena di Pantai Nyalo hanya terdapat 2 unit tempat kios atau warung makan, dan 1 unit terletak di kawasan pantai dan 1 unit lagi terletak di dalam desa.

Sarana dan prasarana yang ada di Pantai Nyalo, 67\% masyarakat dan 77\%wisatawanmenyatakan cukup baik untuk keadaan areal parkir. Prasarana seperti kamar mandi/WC, mushola dan tempat pembuangan sampah responden masyarakat dan wisatawan menyatakan baik; terutama 100\%wisawatan menyatakan menyatakan kondisi baik pada Mushola, karena tidak sulit untuk mencari tempat beribadah di sekitar pantai. Kedua responden memiliki persepsi yang negatif pada prasarana penginapan, 30\% menyatakan kurang baiknya penginapan dan $100 \%$ pada pos informasi. Hal ini karena masyarakat merasa belum siapnya homestay tersebut digunakan karena masih dalam tahap renovasi, hal ini juga yang membuat wisatawan banyak menyayangkan ketidak siapan ini; terutama pada pos informasi, masyarakat menyayangkan kondisi kurang baiknya tempat tersebut, karena pos informasi hanya berbentuk seperti rumah penduduk biasa.53\% masyarakat dan 50\% wisatawan menyatakan baik untuk kondisi tempat sampah di Pantai Nyalo. 50\% masyarakat menyatakan cukup baik untuk kios/ warung makan sedangkan, $47 \%$ wisatawan menyatakan tidak baik, karena kondisi kios yang kurang terawat.

\section{Indeks Kesesuaian Wisata di Pantai Nyalo}

Hasil pengukuran kedalaman di tiga stasiun Pantai Nyalo menunjukkan pantai ini termasuk perairan yang dangkal dengan kedalaman rata-rata adalah $1,17 \mathrm{~m}$. Kedalaman ini tergolong aman untuk kegiatan wisata rekreasi pantai seperti berenang Menurut Haris (2003), perairan dengan kedalaman 0-5 meter dapat digolongkan dalam perairan dangkal. Perairan ini merupakan lokasi yang paling ideal untuk melakukan kegiatan wisata rekreasi pantai karena pengunjung dapat bermain air dengan aman.Pengamatan visual Pantai Nyalo tergolong ke dalam jenis pantai berpasir putih.Indahnya pasir Pantai Nyalo menjadi daya tarik untuk memanjakan wisatawan yang ingin menikmati suasana pantai.Hal ini sesuai dengan Sunarto (1991), tekstur pasir yang halus serta berwarna putih menjadi faktor penting dalam berwisata rekreasi pantai jika dibandingkan pantai berbatu atau pantai berlumpur.Pantai Nyalo menunjukkan lebar pantai tergolong cukup lebar dengan rata-rata 19 m. Lebar pantai sangat berkaitan dengan luasan lahan yang dapat dimanfaatkan untuk berbagai aktivitas rekreasi pantai.Karena kondisi lebar pantai yang luas membuat pengunjung leluasa melakukan aktivitas rekreasi pantai.

Pantai Nyalo memiliki material dasar perairan berupa pasir.Salah satu faktor penting dalam wisata pantai adalah kenyamanan pengunjung bermain pasir.Pasir yang tergolong halus ini memberikan kenyamanan jika dijadikan pijakan kaki. pengukuran kecepatan arus perairan di Pantai Nyalo relatif sangat lemah dengan rata-rata $0,39 \mathrm{~m} / \mathrm{s}$. Lemahnya kecepatan arus di Pantai Nyalo seperti yang telah dikemukankan oleh Wali Nagari Nyalo (2016), dipengaruhi oleh letak dari Pantai Nyalo yang berada di ujung Kawasan Mandeh sehingga terlindungi oleh pulau-pulau kecil di sekelilingnya. Kecepatan arus yang kecil memberikan keamanan wisatawan untuk aktivitas berenang, bermain air dan aktivitas lainnya.Kelebihan Pantai Nyalo adalah bibir pantainya yang sangat landai, bahkan hingga beberapa puluh meter menuju lautnya.Sehingga menciptakan ruang yang lebih luas dan memberikan keamanan untuk bermain-main air tanpa harus takut tersapu ombak.

Pengukuran kecerahan perairan di tiga stasiun di Pantai Nyalo menunjukan hasil yang rendah dengan rata-rata kecerahan $0,83 \mathrm{~m}$. Nilai tersebut menunjukkan bahwa perairan pantai ini kecerahannya tidak sesuai dari standar Yulianda 2007. Namun, nilai kecerahan tersebut tergolong baik mengingat kedalaman perairan yang diamati $<1,5 \mathrm{~m}$. Hal ini karena cahaya matahari yang masuk ke perairan miliki nilai yang hampir mendekati dengan kedalaman perairan, sehingga kondisi perairan Pantai Nyalo masik baik untuk aktivitas wisata pantai. Wilayah Pantai Nyalo terdapat dua kriteria penutupan lahan, yaitu lahan terbuka dan vegetasi pohon kelapa pada stasiun I, sedangkan pada stasiun II dan III semak belukar rendah dah savanna.Penutupan lahan di pantai ini secara tidak langsung memberikan pemandangan pohon-pohon kelapa yang rindang dan hijau serta pemandangan hamparan lahan pasir putih yang sering dijadikan tempat bermain bola ataupun voli anak-anak setempat dan pengunjung pantai.Keberadaan biota berbahaya baik yang berada di daratan maupun perairan berkaitan dengan aspek keamanan dan kenyamanan pengunjung. Apabila pada suatu kawasan wisata ada biota berbahaya di daratan seperti ular ataupun bulu babi di perairan akan mengurangi tingkat keamanan pengunjung, bahkan bisa mengurangi intensitas jumlah pengunjung yang berdatangan. Tidak demikan dengan Pantai Nyalo, berdasarkan hasil pengamatan dan wawancara tidak ditemukan adanya biota berbahaya di kawasan pantai ini.

Keseluruhan kawasan Pantai Nyalo secara umum memiliki karakteristik yang sama. Hal ini dapat dilihat dari hasil persentase kesesuaian (Tabel 2) yang hasil tidak jauh berbeda. Indeks Kesesuaian Wisata (IKW) 
pada stasiun I 96\%, stasiun II dan III 92\% Hasil menunjukkan nilai IKW untuk ketiga stasiun termasuk katogeri $\mathrm{S} 1$ atau sangat sesuai untuk wisata pantai dengan rata-rata persentase $93 \%$.

\section{KESIMPULAN}

Kesimpulan yang didapat pada penelitian ini adalah sebagai berikut:

1. Pantai Nyalo memiliki empat potensi wisata yang dapat dikembangkan menjadi objek wisata, yaitu panorama keindahan di sekitar pantai; aktivitas berenang; lahan pasir putih untuk olahraga pantai; objek panorama di Puncak Paku.

2. Daya tarik wisata seperti pemandangan alam, pasir pantai, rekreasi berenang, dan olahraga pantai di Pantai Nyalo dipersepsikan positif oleh responden, sedangkan kuliner dipersepsikan negatif.

3. Indeks Kesesuaian Wisata (IKW) Pantai Nyalo berdasarkan pengukuran parameter di tiga stasiun, yaitu pada stasiun I 96\%, stasiun II dan III 92\% termasuk kategori S1 atau sangat sesuai untuk wisata pantai.

\section{UCAPAN TERIMA KASIH}

Terima kasih penulis ucapkan kepada Prof. Dr. Ir. Sahala Hutabarat, M.Sc, Dr. Ir. Suryanti, M.Pi dan Dr. Ir. Bambang Sulardiono, M.Si serta Churun Ain, S.Pi, M.Si yang telah memberikan arahan, bimbingan serta kritik dan saran dalam penyusunan jurnal ini. Serta semua pihak yang telah membantu dan memberikan dukungan.

\section{DAFTAR PUSTAKA}

Dinas Kelautan dan Perikanan Kabupaten Pesisir Selatan, 2015.

Haris, A. 2003.Analisis Kesesuaian Lahan dan Kebijakan Pemanfataan Ruang Wilayah Pesisir Teluk Kayeli Kabupaten Buru.[Tesis]. Program Pascasarjana IPB. Bogor. 54 hlm.

Hartono, 2005.Pengembangan Pariwisata Minat Khusus Kesenian Tradisional. Jurnal Seni dan Desain, 1(1): 3-4.

Kusumaningrum, D. 2009. Persepsi Wisatawan Nusantara Terhadap Daya Tarik Wisata Di Kota Palembang.[Tesis]. Magister Kajian Pariwisata Universitas Gajah Mada. Yogyakarta.50 hlm.

Ridwan, N.N H. 2013. Potensi Wisata Selam Kapal Keram di Sumatera Barat. Majalah TROBOSAqua, Edisi 15: 40-41.

Stasiun Meteorologi Kelas IV Maritim Teluk Bayur, 2016.

Sunarto, 1991. Geomorfologi Pantai: Kursus Singkat Pengelolaan dan Perencanaan Bangunan Pantai. Pusat Antar Universitas Ilmu Teknik UGM. Yogyakarta.

Wali Nagari Nyalo Mudiak Air Kecamatan Koto IX Tarusan, 2016.

Yulianda, F. 2007. Ekowisata Bahari Sebagai Alternatif Pemanfaatan Sumberdaya Pesisir Berbasis Konservasi. [Makalah] Departemen Manajemen Sumberdaya Perairan. Institut Pertanian Bogor. 